Jurnal Terapung : Ilmu - Ilmu Sosial , Vol. 3, No. 2, September 2021 ISSN: 2656-2928

\title{
HARUN NASUTION: SEBUAH PEMIKIRAN PENDIDIKAN DAN RELEVANSINYA DENGAN DUNIA PENDIDIKAN KONTEMPORER
}

\author{
Ngalimun, Yusup Rohmadi \\ Email: ngalimunmtp@gmail.com \\ Universitas Islam Negeri Raden Mas Said Surakarta \\ J1. Pandawa, Pucangan, Kec. Kartasura, Kabupaten Sukoharjo, Jawa Tengah 57168
}

\begin{abstract}
ABSTRAK
Penelitian ini termasuk jenis penelitian kepustakaan, yaitu menjadikan bahan pustaka sebagai sumber (data) utama, sehingga lebih sebagai penelitian dokumen (documentary research). Penelitian ini juga termasuk dalam katergori historis-faktual, karena yang diteliti adalah pemikiran seseorang. Dengan demikian, dalam penilitian kepustakaan ini penulis ingin menganalisis tentang pemikiran pendidikan Islam dan relevansinya dengan dunia pendidikan menurut Harun Nasution di Indonesia dan pengaruhnya. Sebagai sarana untuk memudahkan analisis data, dalam kajian kepustakaan ini digunakan beberapa pendekatan segingga dapat memperjelas kajian dalam penelitian. Dalam tulisan ini pula akan membahas tentang Pemikiran Pendidikan Islam Harun Nasution yang kesemuanya tidak jauh dari permasalahan mengenai pembaharuan Islam di era modern. Dengan mengetahui latar belakang, pemikiran dan solusi yang ditawarkan oleh Harun, akan menambah kekayaan keilmuan keislaman yang semoga dapat dimanfaatkan.
\end{abstract}

Kata Kunci: Harun Nasution, relevansi pemikiran pendidikan kontemporer

\begin{abstract}
This research belongs to the type of library research, which makes library materials the main source (data), so that it is more of a document research (documentary research). This research is also included in the historical-factual category, because what is being researched is a person's thoughts. Thus, in this literature research the author wants to analyze the thought of Islamic education and its relevance to the world of education according to Harun Nasution in Indonesia and its influence. As a means to facilitate data analysis, in this literature review several approaches were used so as to clarify the study in research. This paper will also discuss about Harun Nasution's Islamic Education Thought, all of which are not far from the problem of Islamic renewal in the modern era. By knowing the background, thoughts and solutions offered by Harun, it will add to the wealth of Islamic scholarship which hopefully can be utilized.
\end{abstract}

Keywords: Harun Nasution, relevance of contemporary educational thinking 


\section{PENDAHULUAN}

Dalam sejarah Islam, mulanya berkembang pemikiran rasional tetapi kemudian berkembang pemikiran tradisioanal. Pemikiran rasional berkembang pada zaman klasik Islam. pemikiran rasional ini di pengaruhi oleh persepsi/penetimaan tentang bagaimana tingginya kedudukan akal seperti yang terdapat dalam paparan Al-Qur'an dan Hadis. Sedangkan pemikiran tradisional berkembang pada zaman pertengahan Islam (1250-1800 M). Jadi, hingga abad ke -18 umat Islam berada di abad kejumudan.

Baru pada akhir abad 18 atau awal abad 19 muncullah tokoh-tokoh pembaharu yang peduli akan Islam saat ini. Munculnya pembaharu-pembaharu dalam Islam adalah karena adanya ide-ide pembaharuan yang ingin dimunculkan agar Islam bisa mendapatkan kejayaanya kembali. Maka muncullah tokoh seperti Jamal Ad-din AlAfghani, Muhammad 'Abduh, dan sebagainya. Mereka menjadi motor penggerak pembaharu Islam.keadaan seperti ini tertular pula ke lingkungan Indonesia. Muncul cendikiawan muslim Harun Nasution. Ia adalah sosok ilmuan muslim dan salah satu tokoh pembaharu yang sangat terkenal dan cukup disegani oleh kalangan intelektual muslim, baik didalam maupun luar negeri. Setiap kali orang mendengar namanya pasti akan terbayang sosok seorang Rektor IAIN Jakarta yang memiliki keahlian dalam bidang teologi dan filsafat yang bercorak rasional bahkan liberal. Ia juga hadir karena ingin memunculkan ide-idenya yang menurutnya selama ini terjadi kesalah pahaman tentang Islam itu sendiri.

Dalam tulisan ini saya akan membahas tentang Pemikiran Pendidikan Islam Harun Nasution yang kesemuanya tidak jauh dari permasalahan mengenai pembaharuan Islam di era modern. Dengan mengetahui latar belakang, pemikiran dan solusi yang ditawarkan oleh Harun, akan menambah kekayaan keilmuan keislaman yang semoga dapat dimanfaatkan.

\section{LANDASAN TEORI}

Harun Nasution lahir di Pematang Siantar, Sumatra Utara, 23 September 1919. Setelah menyelesaikan pendidikan tingkat dasar, Hollandsch Inlandsch School (HIS), ia melanjutkan studi islam ke tingkat menengah yang bersemangat modernis, Moderne Islamieische Kweekschool (MIK). Karena desakan orang tua, ia meninggalkan MIK dan pergi belajar ke saudi arabia, di negeri gurun pasir ia tidak tahan lama dan menuntut orang tuanya agar bisa pindah studi ke mesir. Di negeri sungai Nil ini Harun mulamula mendalami islam di fakultas ushuluddin, universitas Al-Azhar, namun ia merasa tidak puas dan kemudian pindah ke universitas Amerika (kairo). Di universitas ini harun tidak mendalami islam, tetapi ilmu pendidikan dan ilmu-ilmu sosial. Selama beberapa tahun sempat bekerja di perusahaan swasta dan kemudian di konsulat indonesia kairo setamat dari universitas tersebut dengan ijazah B.A di kantongnya. Dari konsulat itulah, putra batak yang mempersunting seorang putri dari negeri mesir ini, memulai karier diplomatiknya. Dari mesir ia ditarik ke jakarta, dan kemudian diposkan sebagai sekretaris pada kedutaan besar indonesia di prussel. Situasi politik dalam 
negeri indonesia pada tahun 60-an membuatnya mengundurkan diri dari karier diplomatik dan pulang ke mesir. Di mesir ia kembali menggeluti dunia ilmu di sebuah sekolah tinggi studi islam, di bawah bimbingan salah seorang ulama fiqh mesir terkemuka, abu zahra. Ketika belajar di sinilah harun mendapat tawaran untuk mengambil studi islam di universitas McGill, kanada. Untuk tingkat magister di universitas ini, ia menulis tentang pemikiran negara islam di indonesia, dan untuk disertasi Ph.D, ia menulis tentang posisi akal dalam pemikiran teologi Muhammad Abduh. Setelah meraih doktor, harun kembali ke tanah air dan mencurahkan perhatiannya pada pengembangan pemikiran islam lewat IAIN. Ia sempat menjadi rektor IAIN jakarta selama dua periode (1974-1982). Kemudian ia memelopori pendirian pascasarjana untuk studi islam di IAIN

\section{METODE PENELITIAN}

Cara dan jenis penelitian ini termasuk jenis penelitian kepustakaan (library research. Yaitu menjadikan bahan pustaka sebagai sumber (data) utama, sehingga lebih sebagai penelitian dokumen (documentary research). Penelitian ini juga termasuk dalam katergori historis-faktual, karena yang diteliti adalah pemikiran seseorang. Dengan demikian, dalam penilitian kepustakaan ini penuli ingin menganalisis pemikiran Harun Nasution tentang pendidikan Islam di Indonesia dan pengaruhnya. Sebagai sarana untuk memudahkan analisis data, dalam kajian kepustakaan ini digunakan beberapa pendekatan segingga dapat memperjelas kajian dalam penelitian.

\section{PENELITIAN DAN HASIL PEMBAHASAN}

\section{Pemikiran Harun Nasution tentang Pendidikan.}

Harun Nasution dikenal umum sebagai seorang cendikiawan muslim yang sangat rasioanl. Dalam ceramahnya, Harun selalu menekankan agar kaum muslim Indonesia berfikir secara rasional. Ia juga menganjurkan sepatutnya kita dapat meniru syi'ah yang sudah berfikir rasional. Karena pemikirannya ini banyak kalangan yang menolak, tetapi ada juga yang memberi apresiasi, Ia merasa heran mengapa umat Islam harus saklek, padahal ajaran Islam memberikan ruang yang begitu luas kepada umat muslim untuk berinovasi. Menurutnya ajaran Islam yang qat'iyyah Cuma sedikit, seperti tuhan itu ada dan Esa, keharaman riba dan memakan daging babi serta khamar. Bahkan sisanya adalah ayat-ayat yang bersifat dzan'iy dilalah bahkan kalau hadis masih ada yang bersifat dzan'iy alwurud. Untuk itu, menurutnya semua aspek. Bukan hanya aspek fikih. Dalam Islam masih banyak yang kita inovasi tanpa merubah esensi ajarannya. Ia memberi contoh dalam bidang akidah pun ada yang bersifat dzan'iy dilalah dan dzan'iy alwurud. Seperti perihal rukun iman keenam. Karena menurutnya Alqur'an tidak menyebutkan qada dan qadar. Beliau juga setuju dengan sistem penyatuan kelas antara laki-laki dan perempuan. Karena menurutnya tidak ada dalil yang secara terang-terangan melarang itu. Bahkan mengenai hukum waris ia setuju dengan pendapat Munawir Syadzali.

Harun menyatakan bahwa keadaan statis yang melanda di tubuh umat muslim saat ini ialah karena merasa terikat dengan ajaran-ajaran bukan dasar yang 
di hasilkan oleh zaman silam (ijtihad). Sebagai gantinya diperlukan ajaran bukan dasar (ijtihad) baru dengan menimbulkan penafsiran baru dari ajaran dasar yang terdapat dalam Al-Qur'an dan Hadits yang di sesuaikan dengan tuntutan zaman. Harun sendiri mengakuinya dengan berkata :

Aku sendiri memang kurang bisa berbicara dengan kebanyakan orang. Pembicaraanku seringkali terlalu filosofis. Maka seringkali aku diminta untuk berbicara di masjid, kubilang aku tidak bisa. Aku tidak bisa bercerita dongeng kepada mereka. Sebab dongeng tidak masuk akal menurutku. Akupun dipaksa, aku memang datang juga membicarakan apa yang kumiliki. Tapi mereka mengantuk, atau jika dipaksa terus, akhirnya kubilang tidak sanggup karena alasan sudah tua. Namun jika diajak diskusi aku selalu datang. Karena kebanyakan dari mereka adalah dari kalangan intelektual yang mau berfikir rasional. Begitu pula kalau aku mengarang, karanganku diperuntukan orang atas bukan untuk orang awam.

Ia melanjukan:

Harapanku memang Cuma satu, pemikiran Asy'ariyah mesti diganti oleh pemikiran rasional Mu'tazilah, pemikiran filosof atau pemikiran rasional. Caranya Cuma bisa dengan memegang para penguasanya saja. Sayangnya selama ini yang berdakwah banyak dari golongan awam. Golongan intelektual di Indonesia ini tidak kelihatan yang jadi juru dakwah.

Berbeda dengan kaum abangan atau ulama yang bercorak fundamentalis, kaum cendikiawan terlebih yang sepemikiran dengannya, agaknya banyak memberikan pujian atau apresiasi terhadap hal-hal yang telah ditorehkan oleh Harun. Misalnya saja Zuly Qodir yang menyatakan bahwa peran Harun Nasution demikian besar dalam pengembangan citra IAIN Jakarta menjadi sebuah mazhab tersendiri dalam peta pemikiran Islam Indonesia, menggeser posisi ITB, UNPAD, UGM, UNBRAW.

Juga ada mantan menteri Agama Munawir Syadzali yang pernah mengatakan:

"kiranya tidak berlebihan jika saya katakan bahwa kehadiran beliau dalam keluarga besar IAIN telah menghasilkan pola pikir yang maju dan menggalakkan keberanian berpendapat serta keterbukaan terhadap dunia luar".

Nurcholis Madjid seorang cendikiawan muslim terkemuka bahkan dikalangan orientalis mengatakan:

"orang macam Harun telah memberikan bekas terhadap perkembangan keislaman di IAIN seperti menghasilkan suatu gejala umum dimana orang berani berdiskusi secara terbuka, berani mempertanyakan pandangan atau doktrin yang sudah mapan dan tidak melihat doktrin itu sebagai taken for granted. Dia mempertanyakan relevansi doktrin itu kepada sejarah, bagaimana kaitannya dulu dan sebagainya. Inilah yang menghasilakn kemampuan tertentu yang yang secara teknis disebut learning capacity, yaitu kemampuan untuk belajar”.

Madjid melanjutkan :

Yang secara substansi bisa kita lanjutkan dan kita kembangkan dari pak Harun ialah studi atau kajian mengenai kalam(teologi) dan filsafat. Kalam oleh para ahli Barat disebut teologi rasional, tidak seperti teologi kristen yang dogmatis. Kalam itu sangat dialektis dan logis”. 
Menurut madjid salah satu efek Harunisme adalah membuat agama menjadi fungsional, tidak hanya simbol-simbol yang sentimental dan penuh perasaan. Harun Nasution menurut Madjid tidak suka pada dzauqiyat tapi aqliyyah. Kalau dzauq saja, para pengikut kultus jauh lebih mantap, lebih puas dari orang yang beragama. Karena apa? Karena guru-guru kultus selalu mengatakan: "ikut saya pasti masuk surga". Madjid juga menyaksikan sikap beberapa sarjana yang menyatakan bahwa pembaharuan teologis tidak akan berdampak apa-apa pada sisi sosial ekonomi masyarakat. Padahal menurutnya salah.

a. Perubahan Mind-set IAIN

IAIN sebagai lembaga tinggi Islam sudah pasti diarapkan oleh kalangan muslim di Indonesia sebagai lembaga yang dapat memberikan solusi terhadap segala permasalahan agama. Untuk itu disana para mahasiswa dikader untuk bisa menjadi ulama yang menyebarkan Islam keseluruh wilayah Indonesia. Sayangnya, pada mulanya perkuliahan di IAIN mengacu kepada metode AlAzhar di Mesir, dengan titik berat tekanan kepada mazhab Syafi'i. Pada masa itu mata kuliah perbandingan mazhab saja masih dirasakan asing bagi sementara mahasiswa. Setelah perkuliahan semacam ini berjalan belasan tahun, kemudian dipertanyakan mengapa lulusan IAIN berwawasan sempit, tidak berfikiran rasional dan pada umumnya hanya berorientasi akhirat semata. Hal ini dikemukakan oleh menteri agama Mukti Ali dalam musyawarah rektor IAIN di Ciumbuleuit tahun 1973. Untuk itu perlu dibentuk kemampuan rasional. Mahasiswa perlu dikenalkan dengan aspek ilmu kalam, tasawuf, filsafat Islam, bahkan filsafat barat.

Hasil dari musyawarah tersebut akhirnya merestui adanya matakuliah "pengantar ilmu agama" yang harus diberikan kepada seluruh mahasiswa IAIN di Indonesia yang mempelajari Islam dari segala aspeknya. Buku Harun Nasution yang berjudul Islam ditinjau dari berbagai aspeknya dipilih sebagai buku wajib dalam matakuliah pengantar ilmu Agama. Dari sanalah akhirnya pemikiran IAIN sedikit demi sedikit berubah menjadi lebih terbuka dan rasional.

Menurut Nasution untuk menghilangkan kesalah pahaman, perlu mengetahui Islam dari segala aspeknya. Memang tidak mudah, tetapi yang dimaksudkan disini ialah hanya mengetahui secara gari-garis besarnya saja. Sebagai dasar, pengetahuan yang demikian sudah cukup. Kemudian barulah setiap orang boleh mengambil spesialisasi sesuai kesenangan atau bakatnya.

Didalam bukunya ia menjabarkan apa dan bagaimana agama itu, apa definisi Islam dalam pengertian yang sebenarnya. Lalu mengklasifikasikan ajaran-ajaran Islam kedalam beberapa aspek politik, aspek perkembangan, aspek hukum, aspek teologi, aspek filsafat, aspek mistisme, dan aspek pembaharuan dalam Islam. semua dijelaskan melalaui pendekatan sejarah sejak awal tumbuhnya Islam hingga zaman modern.

Tetapi tidak semua menerima secara hangat buku karangan Harun. Seperti H.M Rasyidi dalam bukunya yang mengkritik buku Islam di tinjau dari berbagai aspeknya memandang Harun Nasution sebagai seseorang yang telah dipengaruhi oleh jalan pikiran dan pendekatan orientalis yang tidak selamanya simpatik pada Islam, bahkan merugikan. 
b. Pembaharuan Islam: Sebuah Rasionalisasi Agama

Harun Nasution disebut-sebut sebagai salah satu tokoh pembaharu Islam di Indonesia yang begitu giat memperkenalkan kembali pemikiran rasional mu'tazilah. Maka wajar jika Rasyidi mengatakan bahwa neo-mu'tazilah akan langsung dialamatkan kepada Harun Nasution karena ide dan gagasannya dalam mendobrak faham fatalisme dan taklid buta yang dianut mayoritas muslim Indonesia serta berupaya menghidupkan kembali teologi mu'tazilah yang serba rasional. Tiada lain yang menjadi latar belakang pembaharuan yang dilakukan oleh Harun Nasution dikarenakan keprihatinannya kepada umat Islam yang secara kuantitatif bersifat mayoritas, tetapi dari segi kualitatif yang di indikasikan dengan kontribusi dalam pembangunan bersifat minoritas. Realitas ini yang mendorongnya untuk mencari akar penyebabnya secara mendasar dan kemudian menawarkan solusinya.

Menurut Harun pemikiran rasional mu'tazilah ini pun sudah mulai timbul kembali oleh pemuka pembaharu Islam seperti Jamaludin Al-Afghani, Muhammad Abduh dan sebagainya. Dan pada akhirnya pandangan-pandangan negatif terhadap mu'tazilah pun mulai berubah. Seperti mengenai paham fatalisme yang telah membuat umat Islam mundur. Didalam Al-Urwah al-wusqa 'Abduh dan Al-Afghani menjelaskan paham qada dan qadar telah di selewengkan menjadi fatalisme, sedangkan faham itu sebenarnya mengandung unsur dinamis yang membuat umat Islam maju. Untuk itu, paham fatalisme yang terdapat dikalangan umat Islam saat ini perlu di ubah dengan paham kebebasan manusia dalam kemauan dan perbuatan layaknya paham mu'tazilah. Menurut Harun, inilah yang akan meimbulkan kedinamisan umat Islam kembali.

Harun juga menulis buku Falsafat Islam, buku ini berisi mengenai cara berfikir tentang dasar-dasar agama, mencoba memahami dasar-dasar itu menurut logika dan dengan demikian dapat memberikan penjelasan yang dapat diterima akal kepada orang yang tidak percaya pada wahyu dan hanya berpegang pada pendapat akal. Misalnya saja mengenai keberadaan tuhan. Dalam setiap babnya Harun memberikan argumen-argumen rasional yang dapat diterima oleh semua kalangan bahkan ateis. Menurutnya, pengetahuan agama tidak selalau menggunakan wahyu, melainkan juga dengan penggunaan bukti-bukti historis, argumen-argumen rasional tentang agama dapat mempertebal keimanan seseorang. Dalam buku ini sesungguhnya ia berusaha untuk membuktikan ajaran Islam sangat rasional dan dapat dibuktikan. Seperti yang telah dipaparkan diatas, latar belakang Harun melakukan rasionalisasi dalam Islam dikarenakan minimnya produktivitas umat muslim. Untuk itu ada beberapa saran yang dianjurkan olehnya. untuk membuat umat muslim kembali jaya, diantaranya:

1. Umat Islam harus kembali ke ajaran yang sebenarnya

2. Siap taklid kepada pendapat dan penafsiran lama juga harus ditinggalkan dan pintu ijtihad dibuka. Ajaran-ajaran dasar yang terdapat dalam Al-Qur'an hadis sebagai patokan terhadap perincian-perincian yang cara pelaksanaanya dapat disesuaikan dengan perkembangan zaman. 
3. Dinamika umat Islam harus dibangkitkan lagi dengan menyuburkan pemikiran rasional mu'tazilah dan menjauhkan paham jabariyah. Umat muslim harus dirangsang untuk berfikir dan banyak berusaha lebih maksima.

4. Pendidikan tradisional harus diubah dengan memasukan mata pelajaran tentang Ilmu pengetahuan modern kedalam kurikulum madrasah.

5. Dalam bidang politik, pemerintahan absolut harus diubah menjadi pemerintahan demokratis. Kedalam dunia Islam harus dimasukan sistem pemerintahan konstitusional.

c. Konsep pendidikan menurut Harun Nasution

Konsep pendidikan menururt Harun Nasution harus disesuaikan dengan konsep manusia menurut Al-Qur'an dan hadis. Konsep manusia menurut ajaran Islam, bukan hanya terdiri dari tubuh, seperti yang terdapat dalam filsafat materialisme, tetapi tersusun dari unsur jasmani dan ruhani. Dalam pada itu unsur ruhani bukan pula terdiri hanya dari daya intelek seperti yang terdapat dalam filsafat Barat, tetapi daya berpikir yang disebut akal dan daya merasa yang disebut kalbu. Dengan demikian manusia tersusun dari dua unsur, unsur materi (jasmani atau tubuh) dan unsur immateri (ruh). Tubuh manusia berasal dari tanah dibumi, sedangkan ruh manusia berasal dari substansi immateri di alam ghaib. Tubuh mempunyai daya fisik atau jasmani, seperti mendengar, melihat, mencium, dan daya gerak seperti menggerakan tangan, kaki, kepala dan lainlain. Sedangkan ruh yang juga mempunyai dua daya yakni daya berpikir yang disebut akal yang berpusat dikepala dan daya rasa yang disebut kalbu yang berpusat di dada.

Akal dikembangkan melalui pendidikan sains dan daya rasa melalui pendidikan agama. Dalam sistem pendidikan semacam ini pendidikan agama mempunyai kedudukan yang pentingnya sama dengan pendidikan sains. Keduanya merupakan bagian yang esensial dan integral dari pendidikan umat. Tidak tepat jika didalam pendidikan agama menomorduakan pendidikan sains dan tidak tepat pula jika pendidikan sains dianakemaskan dan pendidikan agama dianaktirikan.

Keduanya harus dipandang sebagai anak emas. Pandangan ini mirip dengan pandangan Fazlur Rahman tentang sistem pendidikan. Karena memang pendidikan dalam pandangan Islam adalah mencetak manusia yang saleh. Khusus mengenai pendidikan agama, baik di lembaga pendidikan umum maupun agama, Harun Nasution menjelaskan bahwa yang dibutuhkan adalah pendidikan agama dan bukan pengajaran agama.

Yang dipraktekkan pada umumnya di perguruan-perguruan kita, baik umum maupun agama selama ini adalah "pengajaran agama" dan bukan "pendidikan agama". Yang dimaksud dengan pengajaran agama adalah pengajaran tentang pengetahuan keagamaan kepada siswa dan mahasiswa, seperti pengetahuan tauhid atau ketuhanan, pengetahuan tentang fikih, tafsir, hadis dan sebagainya. Diantara pengetahuan-pengetahuan yang biasanya dipentingkan adalah fikih dan itu pun pada umumnya hanya berkisar pada ibadah terutama shalat, puasa, zakat dan haji. 
Dengan demikian apa yang disebut pendidikan agama dalam perguruan tinggi, bukan bertujuan menghasilkan siswa dan mahasiswa yang berjiwa agama tetapi mahasiswa yang berpengetahuan agama. Padahal berbeda antara yang berpengetahuan agama dengan orang yang berjiwa agama. Kelihatannya disinilah yang menjadi salah satu penyebab timbulnya kemerosotan akhlak yang terjadi sekarang dalam masyarakat kita. Padahal inti ajaran Islam adalah moral atau akhlak yang mulia, ibadah-ibadah mahdah yang diajarkan Islam pun pada dasarnya merupakan akhlak yang mulia pula. Bahkan Muhammad SAW diutus kedunia dalam rangka memperbaiki akhlak.

Dengan demikian, bahan pendidikan disekolah umum sebaiknya didasarkan pada tujuan moral, spiritual dan intelektual. Sebaliknya tujuan pendidikan agama dilembaga-lembaga pendidikan agama seharusnya bukan lagi hanya menghasilakan agamawan dan ulama tanpa predikat tertentu, tetapi ulama yang berpikiran luas, rasional, filosofis, dan ilmiah, serta teologi rasionalnya, sebagai ganti dari ulama yang berpikiran tradisional yang pada umumnya dihasilkan lembaga pendidikan Islam selama ini. Untuk menghasilkan ulama yang berpengetahuan luas, rasional, filosofis dan ilmiah itu, maka kurikulum mulai madrasah ibtidaiyah hingga perguruan tinggi agama, harus disusuri atas mata pelajaran yang dapat mencapai tujuan itu.

Dalam kaitan ini menurut Harun Nasution, pendidikan tradisional harus diubah, dengan memasukan mata pelajaran tentang ilmu pengetahuan modern (sains) kedalam kurikulum madrasah. Juga mendirikan sekolah-sekolah modern disamping madrasah yang telah ada, sehingga dapat memproduk ahli-ahli Islam dalam bidang ilmu pengetahuan dan teknologi.

Untuk memenuhi gagasannya itu, pada tahun 70-an dan 80-an, Harun Nasution mengadakan refolusi fundamental terhadap IAIN. Menurutnya, sesuai dengan hakekat penciptaan manusia, maka sarjana muslim atau ulama yang harus dihasilkan oleh IAIN adalah sarjana muslim atau ulama yang berkembang akal dan daya pikirnya serta halus kalbu dan daya batinnya. Dengan kata lain, sarjana atau ulama yang dihasilkan IAIN haruslah sarjana muslim dan ulama pengetahuannya bukan hanya terbatas pada pengetahuan agama saja, tetapi juga mncakup apa yang lazim disebut pengetahuan umum, serta akhlak dan budi pekerti yang luhur.

Karena itulah dosen-dosen IAIN tidak dikirim ke Mesir melainkan kedunia Barat untuk mempelajari Islam dari segi metodologinya serta cara berpikir rasional, sehingga mereka akan dapat menjadi ulama yang berpikir rasional.

Dari uraian diatas dapat dikemukakan bahwa pemikiran Harun Nasution tentang pendidikan merupakan usaha beliau mewujudkan tujuan pendidikan Islam agar dapat mewarnai keberagaman masyarakat dalam kehidupan seharihari. Demikian pula pandangannya tentang ajaran dasar dan non dasar, bukanlah untuk membingungkan umat Islam Indonesia, namun justeru mengantarkan umat kepada pemahaman terhadap ajaran Islam secara utuh serta mengeleminir terjadinya konflik akibat klaim kebenaran setiap kelompok dalam masyarakat Islam. paham rasional Harun Nasution tidak identik dengan rasionalisme dalam 
filsafat Barat, namun beliau ingin menunjukkan bahwa sebenarnya ajaran Islam itu rasional dan sekali lagi beliau tidak bermaksud merasionalismekan ajaran Islam.

d. Pembaharuan Pemikiran dalam Islam di Indonesia

Harun Nasution mengusung pembaruan pemikiran keislaman. Dia mengenalkan multi pendekatan dan memperjuangkannya dengan sangat konsisten. Pengaruh pemikirannya sangat kuat dikalangan IAIN dan STAIN seluruh Indonesia dan masih dirasakan sampai sekarang. Banyak buku, terutama buku ajar yang ditulisnya, salah satu yang sangat berpengaruh dan dijadikan buku pegangan dalam berbagai mata kuliah keislaman adalah Islam di tinjau dari Berbagai Aspek. Buku ini mengilhami banyak sarjana muslim Indonesia untuk melihat betapa beragamnya pemikiran yang berkembang dalam Islam. dalam pandangan Nasution, keragaman Islam tersebut didasarkan pada sumber yang sama yaitu teks-teks suci.

Nasution melihat bahwa realitas plural dalam pemahaman keagamaan adalah kenyataan yang tidak bisa di pungkiri, sikap kita terhadapnya haruslah apresiatif, umat Islam Indonesia diharapkan mampu menghargai perbedaan, baik perbedaan yang terjadi anatar umat Islam maupun dengan non muslim. Masalah yang dihadapi umat Islam Indonesia sampai saat ini adalah kurang berkembangnya pandangan pluralistik atau penghargaan terhadap atas perbedaan dikalangan umat. Pada zamannya, pengajaran keagamaan sangat normatif dan terpaku pada salah satu paham atau aliran pemikiran, atau bahkan kelompok atau pemikiran orang tertentu dan sangat fikih oriented. Metode pendidikan yang seperti ini dapat dipastikan akan menghasilkan lulusan yang mempunyai pemahaman dan pemaknaan agama yang sempit. Dampak negatifnya adalah kemungkinan munculnya pemahaman yang melihat segala hal yang berbeda dengan paham tersebut sebagai salah, menyimpang dan bahkan sesat.

Pada gilirannya, sikap ini menghasilkan pandangan homogen yang menolak perbedaan dalam melihat persoalan-persoalan melalui perspektif agama. Implikasi jauh dari sikap tersebut dapat menjauhkan umat dari partisipasinya dalam pembangunan bangsa. Salah satu jalan kuncinya adalah umat Islam Indonesia harus berpikiran rasional, terbuka, dan toleran. Nasution mengingatkan bahwa umat Islam adalah bagian terbesar bangsa Indonesia. Karenanya, umat Islam harus bertanggung jawab dan ikut serta dalam pembangunan bangsa Indonesia.

Bagi Nasution, ketika orde baru mengambil sikap untuk mengadopsi pembangunan modern. Umat Islam harus ikut serta dan menjadi bagian penting dalam proses tersebut, Nasution mencari akar pembenarannya dalam teologi rasional ala mu'tazilah dan mengenalkannya kepada masyarakat Indonesia lewat buku dan pengajarannya di IAIN dan program pasca sarjana IAIN Jakarta. Selama menjadi rektor (1973-1984) dan setelahnya sampai tahun 1990-an sebagai direktur pada program studi lanjutan pertama yang dibuka IAIN Jakarta. Nasution mengembangkan pemikiran Islam rasional dan menjadikan program 
S1 dan pasca sarjana IAIN Jakarta sebagai agen pembaharuan pemikiran dalam Islam dan tempat penyemaian gagasan-gagasan keislaman yang baru.

\section{Relevansi/Implikasi pemikiran pendidikan Harun Nasution di era Modern.}

Relevansi adalah kecocokan atau saling keterkaitan. Harun Nasution adalah salah satu tokoh pembaharu yang pemikirannya masih dipakai hingga sekarang ini. Salah satunya adalah perubahan mind set IAIN. IAIN sebagai lembaga pendidikan tinggi Islam dulunya adalah perguruan tinggi yang pemikirannya masih tradisional, sistem belajarnya juga masih tradisional. Pada mulanya perkuliahan IAIN mengacu pada metode Al-Azhar dengan titik berat penekanan pada mazhab Syafi'i.

Setelah perkuliahan ini berjalan belasan tahun, kemudian dipertanyakan mengapa lulusan IAIN berwawasan sempit, tidak berfikiran rasional dan pada umunya hanya berorientasi akhirat. Buku Harun Nasution yang berjudul Islam ditinjau dari berbagai aspeknya menjadi buku wajib pengantar Ilmu agama. Dari sanalah akhirnya pemikiran IAIN sedikit demi sedikit mengalami perubahan menjadi lebih terbuka dan rasional.

Didalam bukunya ini ia menjabarkan apa dan bagaimana agama itu, apa definisi Islam dalam pengertian yang sebenarnya. Lalu mengklasifikasikan ajaranajaran Islam kedalam beberapa aspek ibadah, latihan spiritual, moral, aspek sejarah dan kebudayaan, aspek politik, aspek perkembangan lembaga-lembaga kemasyarakatan, aspek hukum, aspek teologi, aspek filsafat, aspek mistisme dan aspek pembaharuan dalam Islam. semua dijelaskan melalui pendekatan sejarah sejak awal tumbuhnya Islam hingga zaman modern.

Menurut Harun Nasution umat Islam khususnya lingkungan IAIN, harus berani mempertanyakan tradisis pemikiran Islam yang selama ini dianggap mapan dan mengadakan terobosan-terobosan liberal. Harun juga ingin menjadikan Pascasarjana IAIN sebagai lembaga ilmiah yang menampung berbagai pemikiran, meskipun bertentangan, sehingga berkembang menjadi dinamika yang sangat berguna bagi pengkayaan mahasiswanya.

Sejak menjadi rektor Harun menata IAIN menjadi kampus pembaharuan pemikiran Islam di Indonesia. Harun memberi ruang yang sangat luas untuk pertumbuhan dan perkembangan pemikiran-pemikiran rasional. Dengan usahanya IAIN cukup di perhitungkan. IAIN bukan hanya perguruan tinggi tradisional, tapi sebuah kampus Islam pembaharu dan modern.

Kebebasan berfikir dan mengemukakan pendapat mahasiswa masih di terapkan hingga sekarang pada lingkungan IAIN, itu merupakan terobosan Harun Nasution agar mahasiswa tidak mempunyai pikiran yang sempit. Tapi saat ini pendidikan semakin banyak problem, Islam saat ini semakin terbelakang dan ketinggalan zaman. Sehingga timbul pertanyaan di hati saya, bagaimana mengembalikan zaman kemegahan umat islam yang dulu-dulu? Jawabannya adalah "Islam harus berani mengejar zaman". Bukan seratus tahun, tetapi seribu tahun Islam ketinggalan zaman. Kalau Islam tidak cukup kemampuan buat mengejar seribu tahun itu, niscaya ia akan tetap hina dan mesum. 


\section{KESIMPULAN}

Harun Nasution adalah sosok ilmuan Muslim yang sangat berwibawa dan disegani oleh kalangan intelektual muslim, baik dalam maupun luar negeri, dan sekaligus menjadi sumber timbulnya berbagai masalah yang menimbulkan perdebatan setiap kali orang mendengar namanya, yang terbayang adalah bahwa ia seorang mantan Rektor UIN Syarif Hidayatullah Jakarta yang memiliki keahlian dalam bidang teologi dan filsafat yang bersifat rasional.

Dengan corak pemikiran teologinya yang demikian itu, Harun Nasution dikenal pula sebagai ilmuan yang banyak mengemukakan gagasan dan pemikiran yang berbeda dengan pemikiran yang umumnya dianut umat Islam Indonesia. Melalui berbagai karya tulis yang dihasilkannya, Harun Nasution tidak hanya memperkenalkan teologi rasional dan liberal seperti Mu'tazilah dan Asy'ariyah yang banyak dianut oleh umat Islam di Indonesia, melainkan juga memperkenalkan yang rasional dan liberal seperti Mu'tazilah dan Maturidiyah Samarkand.

Gebrakan yang paling penting dilakukan oleh Harun untuk mengangkat umat Islam dan Indonesia adalah mempelopori berdirinya Fakultas Pascasarjana dengan maksud untuk mencetak pemimpin umat Islam masa depan. Menurutnya, pemimpin harus rasional, mengerti Islam secara komprehensi, tahu tentang agama dan filsafat. Pemimpin seperti itulah yang diharapkannya lahir dari Pascasarjana.

Usahanya untuk mengangkat lembaga pendidikan Islam (IAIN), terasa sangat luar biasa. Di IAIN Syarif Hidayatullah Jakarta misalnya, kehidupan intelektual akademisnya menjadi lebih hidup. Kondisi seperti itu juga telah mulai terbangun di seluruh IAIN di Indonesia.

Pembaharuan yang dilakukan oleh Harun tidak hanya menyangkut Mahasiswanya tetapi juga para Dosen yang ada dilingkungan IAIN. Untuk meningkatkan mutu dosen dibentuk forum diskusi regular mingguan dan bulanan sebagai media untuk memecahkan masalah-masalah krusial yang didalamnya berkumpul beberapa ahli di bidangnya masing-masing, baik dari IAIN maupun dari luar.

Ia juga merintis terbitnya majalah yang dapat dijadikan sarana untuk menyalurkan gagasan, pikiran dan ide para Dosen dan Mahasiswanya. Beberapa usaha yang telah dilakukan oleh Harun Nasution dengan pembenahan berbagai sektor telah melahirkan satu citra IAIN sebagai pusat studi pembaruan pemikiran Islam. Obsesinya untuk menghadirkan IAIN sebagai pusat dan arus lalu lintas pemikiran-pemikran keislaman, juga sangat di dukung oleh bangsa Indonesia yang mayoritas penduduknya beragama Islam dan memiliki pemerintahan yang memberikan tempat terhormat bagi Usaha pembinaan umat beragama. 
Jurnal Terapung : Ilmu - Ilmu Sosial , Vol. 3, No. 2, September 2021 ISSN: 2656-2928

\section{DAFTAR PUSTAKA}

Akhyar Yusuf Lubis. 2016. Filsafat Ilmu: Klasik Hingga Kontemporer, Jakarta: PT Raja Grafindo Persada.

Aqib Suminto. 1989. Refleksi Pembaharuan Pemikiran Islam: 70 tahun Harun

Nasution. Jakarta: Lembaga Studi Agama dan Filsafat.

Bakhtiar, Amsal. 2009. Filsafat Ilmu. Jakarta: PT. RajaGrafindo Persada.

Harun Nasution. 1973. Filsafat dan Mistisisme dalam Islam. Jakarta: Bulan Bintang. Harun Nasution. 1974. Islam di Tinjau dari Berbagai Aspeknya. Jakarta: UI Press.

Harun Nasution. 1975. Pembaharuan dalam Islam Sejarah Pemikiran dan Gerakan. Jakarta: Bulan Bintang.

Harun Nasution. 1989. Islam rasional gagasan dan pemikiran. Jakarta: Lembaga Studi Agama dan Filsafat.

Latifah. 2019. Filsafat Ilmu: Paradigma baru dalam Pendidikan Islam. Yogyakarta: Parama Ilmu

Syamsul Kurniawan. 2016. Pemikiran Pendidikan Islam Soekarno. D.I Yogyakarta: Samudera Biru.

Sunanto, Musyrifah. 2007. Sejarah Islam Klasik: Perkembangan Ilmu Pengetahuan Islam, Jakarta: Kencana.

Surajiyo. 2013. Filsafat Ilmu dan Perkembangannya di Indonesia. Jakarta: Bumi Aksara 